\title{
Lasten- ja nuortenkirjallisuutta tutkimassa
}

Länsimainen lasten- ja nuortenkirjallisuus on syntynyt pitkälti didaktisista lähtökohdista. Vaikka lajit ovat sittemmin kokeneet monenlaisia sisällöllisiä, esteettisiä ja kirjojen käyttöfunktioon liittyviä muutoksia, elää vanhahtava ajatus lasten ja nuortenkirjallisuuden kasvatuksellisuudesta yhä myös kirjallisuudentutkijoiden parissa. Lasten- ja nuortenkirjallisuudentutkimuksella haetaan usein ratkaisuja tai vastauksia aikuisten pohdintoihin kirjallisuuden vaikutuksista lapsiin ja nuoriin. Didaktisista lähtökohdista syntyvä tutkimus asettuukin toisinaan tahattomasti tutkimuslähtökohtiin, jotka painottavat lasten- ja nuortenkirjallisuuden välinearvoa. Näitä asetelmia väheksymättä on syytä todeta, että lasten- ja nuortenkirjallisuus on tutkimuskohteena arvokas itsessään, lapsille ja nuorille kirjoitettuna kaunokirjallisuutena. Lasten- ja nuortenkirjat ovat sanataidetta siinä missä aikuisille suunnattu kirjallisuus.

Lastenkirjallisuus on laaja käsite, jonka alle luetaan kuuluvaksi usein myös nuortenkirjallisuus. Yhdessä lasten- ja nuortenkirjallisuus kattavat alleen lukuisia lajityyppejä realistisesta kerronnasta spekulatiivisen kirjallisuuden jatkuvasti monipuolistuvaan kirjoon. Lapsille ja nuorille kirjoitetaan yhtä lailla kauhua, romantiikkaa, scifiä ja fantasiaa kuin nonsensea ja realistis-yhteiskunnallista kirjallisuutta. Myös lukijakunnan ikäjakauma ja siten kirjaan kohdistuvat vaatimukset, toiveet ja odotukset vaihtelevat. 2-vuotias on lukijana erilainen kuin 8-vuotias, joka taas on erilainen kuin 15-vuotias. Lasten- tai nuortenkirja voikin määrittelyllisesti olla yhtä hyvin taaperoikäisen koskettelukirja, lasta ja aikuista kuvan ja sanan yhteistyöllä puhutteleva kirja, alakouluikäisen maailmaan keskittyvä romaani, kertomus 16-vuotiaiden ensirakkaudesta tai nuorille aikuisille suunnattu dekkari.

Lajin määrittyminen tarkoitetun yleisönsä kautta on kirjallisten lajien kirjossa ainutkertaista ja tekee osaltaan tarkasteltavasta aineistosta lavean, ja lasten- ja nuortenkirjallisuuden lajien yhdistäminen laventaa kuvaa entisestään. Lasten- ja nuortenkirjallisuudesta tehdyt tutkimukset ovatkin tutkimusalan suhteellisen lyhyestä historiasta huolimatta jo varsin heterogeeninen joukko. Suuria linjoja hahmoteltaessa didaktisten lähtökohtien lisäksi lastenkirjallisuuden kysymyksenasettelut limittyvät usein kysymyksiin esimerkiksi vallasta, kielestä, sukupuolesta ja kulttuurista. Aiheisiin on paneuduttu tarkastelemalla lasten- ja nuortenkirjojen henkilöhahmoja, viihteellisen kirjallisuuden geneerisiä piirteitä, tuotantokoneistoa, palkintojärjestelmiä ja kustannustoimintaa, lukijuutta, adaptaatioita, yhteiskunnan ja kirjallisuuden suhdetta sekä ideologisia, poliittisia ja historiallisia vaikutussuhteita. Oma monimetodinen tutkimusalueensa on vielä esimerkiksi kuvakirjojen tutkimus. 
Lasten ja nuortenkirjallisuudentutkimusta yhdistää ennen kaikkea tarkasteltu aineisto, ei niinkään tietty teoriavälineistö. Tämä ei tarkoita, etteikö erityistä lasten- ja nuortenkirjallisuudentutkimusta tarvittaisi. Esimerkiksi laji(e)n (historiallisen) kehityksen tarkastelu ja lasten- ja nuortenkirjallisuuteen liittyvät ainutlaatuiset kysymykset yleisön puhuttelemisesta vaativat juuri lasten- ja nuortenkirjallisuudentutkimuksen kontekstin tuntemusta. Lastenkirjallisuuden teemanumerolla emme silti halua viestiä, että lasten- ja nuortenkirjallisuutta olisi tarkasteltava vain sille varatussa tutkimuslokerossa. Päinvastoin, sitä tulee tarkastella myös osana muuta kirjallista kulttuuria: mikään ei estä soveltamasta lasten- ja nuortenkirjallisuuteen samoja teorioita ja metodeita, joita käytetään perinteisemmin aikuisille suunnatun kirjallisuuden tutkimukseen. Tämän Avaimen lasten- ja nuortenkirjallisuuden teemanumero tarjoaakin näkymän ajankohtaisiin yhteiskunnallisiin ilmiöihin, kansainvälisiin trendeihin, kirjallisuudelliseen lastenkirjatutkimukseen sekä (lasten)kirjakentällä paljon puhuttaviin kysymyksiin digitalisoitumisesta.

Vaikka lasten- ja nuortenkirjallisuuteen on sovellettu monenlaisia tutkimusmenetelmiä, kokeellista lastenkirjallisuudentutkimusta on julkaistu tähän mennessä hyvin vähän - siitäkin huolimatta, että lastenkirjallisuus on tarjonnut kirjoittajille mahdollisuuksia kokeelliseen sanataiteeseen. Heta Marttisen artikkeli on kokeileva luenta Veera Salmen Puluboin ja Ponin kirjasta (2012). Mitä seuraa, kun R-kirjain tabuoidaan lastenromaanissa? Millaisena kokeellisena lastenkirjallisuutena Salmen romaani näyttäytyy? Marttinen hyödyntää analyysissaan kielellisiin tabuihin ja kielen tabuoitumiseen liittyvää rajoitteen (ra. contrainte) käsitettä.

Viime vuosina varsinkin angloamerikkalaisessa nuorten aikuisten kirjallisuudessa dystooppiset, postapokalyptiseen tulevaisuuteen sijoittuvat teokset ovat olleet myyntimenestyksiä, joista on tehty myös elokuva-adaptaatioita. Jyrki Korpua paneutuu artikkelissaan postapokalyptisen nuorten fiktion lainalaisuuksiin tarkastelemalla K. K. Alongin nuortenromaania Kevätuhrit (2016). Korpua suhteuttaa artikkelissaan suomalaisen dystopiaromaanin piirteitä kansainväliseen lajityyppiin ja aiempaan kaunokirjallisuuteen.

Monikulttuurisuus, etnisyys ja rodullistamiseen liittyvät kysymykset ovat nousseet keskeisiksi paitsi tutkimuksen kentillä ylipäätään, myös lasten- ja nuortenkirjallisuudentutkimuksessa. Jaana Pesosen artikkeli Aino Havukaisen ja Sami Toivosen suositusta Tatu ja Patu -sarjasta tarkastelee Suomen kansallista tarinaa ja uudenlaisen suomalaisuuden tuottamista. Pesonen keskittyy alun perin vuonna 2010 julkaistun Tatun ja Patun Suomi -teoksen päivitettyyn painokseen Tatun ja Patun päivitetty Suomi (2017). Millainen on Tatun ja Patun kautta syntyvä kuva monikulttuurisesta Suomesta ja suomalaisuudesta?

Valta on keskeinen käsite ja tutkimuskohde nuortenkirjallisuudentutkimuksessa, sillä nuortenkirjat käsittelevät valtaa usein monista eri näkökulmista. Valta, väkivalta ja sukupuoli ovat myös Mia Österlundin analyysin keskiössä. Österlund tutkii Maria Turtschaninoffin nuorille ja nuorille aikuisille suun- 
nattuja fantasiaromaaneja Maresi (2014) ja Naondel (2016). Punaisen luostarin kronikoiden sarja nostaa esiin tyttöjen ja naisten aseman, tasa-arvon, tiedon ja väkivallan sukupuolittumisen kysymyksiä.

Digitaalinen kirjallisuus herättää lasten- ja nuortenkirjallisuuden kentällä uudenlaisia kysymyksiä. Lastenkirjallisuuden digitaaliset sovellukset ovat oivallinen esimerkki siitä, että lastenkirjallisuus on usein ollut eturintamassa kirjallisen ilmaisun uudistamisessa. Raine Koskimaa ja Linda Lahdenperä valottavat artikkelissaan lastenkirjallisuuden digitalisoitumista leikillisyyden ja pelillisyyden näkökulmista. Miten digitaalinen lastenkirjallisuus sovelluksineen asettuu jatkumoon, jossa ovat esimerkiksi kuva-, koskettelu- ja pop up -kirjat? Entä kuinka lastenkirjasovellukset voivat tukea leikillistä ja pelillistä lukemista?

Erilaiset pelot ovat osa lapsen normaalia kehitystä, mutta lapsuusajan pelkoihin suhtaudutaan usein vähättelevästi. Lasten- ja nuorten kauhukirjallisuuden kautta työstetään kuitenkin sekä kehityksellisiä pelkoja että eettisiä kysymyksiä. Esimerkiksi näin keskustelevat Susanne Ylönen ja Päivi HeikkiläHalttunen dialogimuotoon kirjoitetussa katsauksessaan kauhusta ja lukijuudesta lastenkirjallisuudessa. Kauhu pitää varpaillaan niin lapsilukijat kuin varsinkin heidän lukukokemuksiaan vartioivat aikuiset. Ylönen ja HeikkiläHalttunen marssittavat keskustelussaan lukijan eteen kummituksia, mörköjä, vampyyreita ja muita hämärän, pimeän ja pelon hahmoja.

Numeron arvosteluissa pureudutaan kirjallisuuskasvatukseen, tyttökirjallisuuteen ja lastenkauhuun. Marleena Mustola tarkastelee Päivi Heikkilä-Halttusen kirjallisuuskasvatusopasta Lue lapselle! (2015). Viime vuosina suomalainen lasten- ja nuortenkirjallisuudentutkimuksen kentällä on tehty kiinnostavia avauksia, joista Hellevi Hakala paneutuu arviossaan Myry Voipio väitöskirjaan Emansipaation ja ohjailun ristivedossa. Suomalaisen tyttökirjallisuuden kehitys 1889-2011 (2015). Sanna Tapionkaski puolestaan tarkastelee Susanne Ylösen väitöstyötä Tappeleva rapuhirviö. Kauhun estetiikka lastenkulttuurissa (2016).

Lasten- ja nuortenkirjallisuus on pitkään pysynyt kirjallisuudentutkimuksen reuna-alueilla. Osin tämä liittyy lasten- ja nuortenkirjallisuuden yleiseen arvostukseen: Edelleenkin esimerkiksi Helsingin Sanomien vuosittaisessa esikoiskirjapalkintouutisoinnissa mahdollisina ehdokkaina mainitaan vuosikausia lasten- ja nuortenkirjoja kirjoittaneita kirjailijoita, jotka vasta "nyt" julkaisevat "esikoisteoksensa". Tämänkaltainen uutisointi on yksi niistä syistä, miksi lasten- ja nuortenkirjailijat kokevat edelleen tulevansa toisinaan kohdelluiksi toisarvoisina kirjailijoina. Tutkimuksen kentillä tilanne on kuitenkin hiljalleen muuttunut, kun lasten- ja nuortenkirjallisuuden tarjoamat tutkimusmahdollisuudet ovat innostaneet monipuoliseen - usein monitieteiseenkin - tutkimukselliseen lähestymiseen.

Hieno, pieni kiekura, sureksi en tahdo ma! (Astrid Lindgren 1948),

\section{Myry Voipio \& Maria Laakso}

